\title{
PRISÃO DO DEVEDOR DE PENSÃO ALIMENTÍCIA NO DIA DA ELEIÇÃO
}

\author{
ANDRÉIA TEIXEIRA MARINHO BARBOSA
}




\section{PRISÃO DO DEVEDOR DE PENSÃO ALIMENTÍCIA NO DIA DA ELEIÇÃO}

Andréia Teixeira Marinho Barbosa ${ }^{1}$

RESUMO:

Uma das situações que sempre causa alguma perplexidade aos homens do povo e preocupação pelos órgãos judiciais em véspera das Eleições diz respeito à vedação de prisão de eleitores e candidatos nos prazos do artigo 236 da Lei 4.767/65 do Código Eleitoral. Sob as luzes deste problema o tema central abordado neste artigo científico explora a defesa da possibilidade dos Magistrados determinarem a segregação do devedor de pensão alimentícia e das autoridades de cumprirem estes e outros mandados de prisão já expedidos neste período vedado por Lei que se faz nos cinco dias que antecedem às Eleições até 48 depois do seu encerramento. É notória a falta de amparo a aplicação do art. 236 do Código Eleitoral o que tem levado os doutrinadores considerálo revogado ou então flexibilizar sua aplicação, com afirmações de que a vedação à prisão referida é inconstitucional e que traz mais danos e revoltas a toda nossa sociedade o seu cumprimento e um sentimento de desalento com o sistema da Justiça Brasileira.

Palavras-chave: Eleição. Prisão. Alimentos. Efetividade.

\section{RESUMEN:}

Una de las situaciones que siempre provoca cierta confusión a los hombres del pueblo y los tribunales preocupación en vísperas de las elecciones se refiere al cierre de la prisión de los votantes y candidatos dentro de los plazos del artículo 236 de la Ley 4.767/65 del Código Electoral. Bajo la luz de este problema, el foco se abordan

\footnotetext{
1 Analista Judiciária do Tribunal de Justiça do Estado do Tocantins, atualmente lotada no Núcleo de Formação e Aperfeiçoamento de Magistrados da Escola Superior da Magistratura Tocantinense. Pós-graduada (lato sensu) em Direito Eleitoral pela Universidade do Tocantins UNITINS. Artigo Jurídico apresentado como trabalho de conclusão do curso de pós-graduação lato sensu de Direito Eleitoral. andreiamarinho@tjto.jus.br
} 
en El presente artículo se analiza la posibilidad de la defensa de los magistrados determinar la segregación del deudor de la pensión alimentaria y las autoridades para cumplir estas y otras órdenes de detención ya han consignado este período prohibido por la ley que está dentro de los cinco días Anterior a las elecciones hasta 48 oras después de su cierre. Se trata de una notoria falta de refugio a la aplicación del art. 236 del Código Electoral que ha llevado a los doutrinadores consideramos derogada o facilitar su aplicación con las reclamaciones que la valla a la cárcel que es inconstitucional y que trae más daños y levantamientos en toda nuestra sociedad. El su conformidad con una sensación de decepción con el sistema de Justicia Brasileña.

Palabras-clave: Elección. Prisión. Alimentos. Eficacia.

\section{INTRODUÇÃO}

O núcleo do presente trabalho é propor aos aplicadores do Direito uma reflexão da aplicação literal do artigo 236 do Código Eleitoral, pelos Juízes em geral, que inclusive vem sendo confirmada pelos Ministros do Tribunal Superior Eleitoral, nos casos em que se tratar da prisão civil do eleitor por dívidas de caráter alimentar nos cinco dias que antecedem às Eleições até 48 depois do seu encerramento.

$\mathrm{O}$ tema abordado diz respeito à garantia e colisão de dois direitos fundamentais do cidadão, quais sejam: a garantia da liberdade de voto do eleitor e o direito aos alimentos, ligado intrinsecamente este último ao direito à vida, emergente do direito da personalidade e do Princípio Constitucional da Dignidade da Pessoa Humana.

Esta problemática deve ser trabalhada sob a égide 
da ordem constitucional e tem-se como inquestionável para RÜFNER, que o direito à vida tem precedência sobre os demais direitos individuais, uma vez que é pressuposto para o exercício de outros direitos ${ }^{2}$.

Este é um assunto até o momento pouco explorado, o que amplia as possibilidades de se discorrer sobre o mesmo numa concepção do grande desafio da interdisciplinaridade, cabendo a sociedade, ao Estado e à família atuarem conjuntamente em todas às áreas de proteção da infância, adolescência e outros possíveis alimentantes. Assim, assegurar a todos um nível essencial de dignidade da pessoa humana que, inclusive, enseja a necessidade de sobre ele dar-se inicio a uma teorização.

Do ponto de vista teórico defendido por BOBBIO

os direitos do homem, por mais fundamentais que sejam, são direitos históricos, ou seja, nascidos em certas circunstâncias, caracterizadas por lutas em defesa de novas liberdades contra velhos poderes, e nascidos de modo gradual, não todos de uma vez e nem de uma vez por todas. ${ }^{3}$

Partindo dessa premissa, estabelecemos a estrutura deste trabalho, que compreende a análise sistemática de um roteiro composto de três capítulos, seguindo-se as conclusões.

O primeiro capítulo, "Razões históricas da vedação à prisão do eleitor no período eleitoral", consiste numa análise

2 RÜFNER, Grundrechtskonflikte, op. cit., p. 453 (462) in FARIAS, Edilsom Pereira. Colisão de Direitos: a honra, a intimidade, a vida privada e a imagem versus a liberdade de expressão e informação. Porto Alegre: Sergio Antonio Fabris, 1996, p. 11

BOBBIO, Norberto. A Era dos Direitos, Ed. Campus, 1992, p.5 
conceitual da prisão e seus objetivos sociológicos e numa segunda vertente o estudo das transformações surgidas pela Justiça Eleitoral criada em 1932, sua evolução histórica até os nossos dias atuais, traçando os caminhos de rompimento com os desmandos do "coronelismo" e da prática do voto do cabresto, período de transição em que se fez necessário proibir qualquer que seja as ordens de prisões no período eleitoral o que não combina com o cenário político vigente em que vivemos na plenitude de um processo político democrático.

No segundo capítulo, "Aplicação do Artigo 236 do Código Eleitoral e a defesa do direito a alimentos e da obrigação alimentar" pretendeu-se examinar as garantias eleitorais e aplicação do artigo 236 nos dias atuais, tecendo comentários de sua inconstitucionalidade face ao legalismo arcaico e exagerado " para os tempos atuais. Procedeu-se a um apanhado de situações em que na interpretação do art. 236 do Código Eleitoral é cabível a prisão provisória de eleitores no período eleitoral e ainda analisamos a insatisfação dos juristas com a rigidez do texto legal nas situações quando o direito do voto sobreleva em especial com a defesa dos interesses dos titulares ao direito dos alimentos essencial a integridade física e a preservação da vida humana.

No terceiro capítulo, "Judiciário e garantias dos direitos fundamentais", enfoca-se o papel deste Poder diante dos novos paradigmas sociais. Observa-se que o grau de participação do magistrado no deslinde da questão constitui um dos aspectos fundamentais no sistema marcados pela busca de realização da 
justiça social, pois suas sentenças se cumpridas, ensejarão, para sua eficácia, os direitos e garantias aos indivíduos satisfazendo suas necessidades humanas básicas, solucionando problemas sociais.

Resta considerar que buscamos ao longo deste estudo elaborar uma reflexão em torno do tema da colisão de dois direitos fundamentais de aplicação imediata pelo Poder Judiciário. As garantias constitucionais dos direitos em geral e dos direitos fundamentais só adquirem sentido quando se dispõe de um aparelho judiciário apto a transformá-las em realidades concretas. Assim é absolutamente necessário que os operadores do Direito passem a enxergar que não somente o indivíduo tem direito, mas que o menor, a família precisam viver com dignidade, princípio de magnitude constitucional, art. $1^{\circ}$, III da CF tendo assim o Estado sua razão maior de ser na proteção à vida.

Essas reflexões, enfim, denunciam não apenas a omissão estatal que vem sopesando o direito de voto e o direito à vida do credor alimentício e que decide pelo livre exercício do sufrágio concedendo salvo-condutos de uma semana a centenas de devedores de alimentos sujeitos a medida constritiva da liberdade tendo como aparato uma norma visivelmente inconstitucional para os dias atuais.

Nesta linha de raciocínio, o cumprimento das decisões judiciais, visando à proteção dos interesses fundamentais afetos à infância e à juventude, consiste num estudo interdisciplinar e relevante instrumento para obtenção de direitos imprescindíveis 
à vida humana.

\title{
2 RAZÕES HISTÓRICAS DA VEDAÇÃO À PRISÃO DO ELEITOR NO PERÍODO ELEITORAL
}

Como toda história viva e contínua, o processo de democratização no Brasil é fruto de uma operação historicamente complexa e longa. Complexa, por ter vivido

\begin{abstract}
grande quantidade de transformações políticas, num tempo relativamente curto - medido em termos históricos. Em trinta anos o País passou por uma crise do sistema parlamentar que vigorava desde o final da Segunda Guerra, dali para um golpe de Estado e uma ditadura militar que transformou radicalmente o Brasil, com suas etapas ascendentes e seu período de crise, até chegar a transição para um novo regime, que se concluiu com a eleição, pelo voto direto, de um novo presidente da República (SADER, 1990).
\end{abstract}

Neste período de transição democrática também ocorreu movimentos de "restabelecimento da ordem social", tendo sido esta ordem reimposta a ferro e fogo, pela repressão aos líderes sindicais, estudantis, intelectuais, aos artistas, políticos, partidos e organizações sociais e longa pela ocorrência de "acontecimentos articulados entre si por pactos de elite, fiados pela força militar" 4 .

Dentro desse quadro social político, SADER soube

SADER, Emir. A Transição no Brasil - Da Ditadura à Democracia? São Paulo: Atual, 1990, p. 1 e 8. 
descrever bem os acontecimentos do sistema legal vivido onde

a doutrina de segurança nacional foi a ideologia oficial da ditadura militar Assim qualquer manifestação de antagonismos, de discrepância, é considerada como um vírus externo, que penetra no organismo apenas para obstacularizar seu bom funcionamento. Nessa qualidade, ela deve ser tratada como um tumor - isto é, deve ser extirpado em nome do funcionamento solidário do organismo social $^{5}$

Apoiado nessa concepção totalitária, o Judiciário foi depurado dos juízes já que poderiam representar obstáculos às medidas de força implementada pelos militares que montaram um gigantesco aparato para recolher informações e punir pessoas e grupos que se mobilizavam contra o sistema através de supressão da liberdade mediante o recolhimento destes indivíduos considerados na época de "inimigos internos".

Neste mesmo contexto, denominado República Velha (1889-1930), as fraudes nas eleições eram costumeiras, como se pode aferir do seguinte texto:

Embora a idéia de democracia e de repartição do poder já estivesse positivada, não tardou a ocorrência de eleições maculadas pelas fraudes. Para tanto, dois mecanismos eram constantemente utilizados, qual seja, o "bico de pena" e a "degola" ou depuração. A falsificação dos resultados pelo método "bico de pena" era praticada pelas mesas eleitorais, que prosseguiam com o oficio de junta apuradora, inscrevendo como eleitores pessoas fictícias, 
mortas e ausentes. Numa etapa posterior, realizada pela Comissão de Verificação de Poderes do Senado e da Câmara, "degolavam-se", ou seja, cassavam-se os diplomas de eleitos "que fossem considerados inelegíveis ou incompatíveis com o exercício do cargo". Desta forma, observando-se a freqüência destes dispositivos, ficaram convencionadas três ocasiões de fraudes: "na eleição, na apuração e no reconhecimento". Tais episódios não se restringiram somente à esfera do grupo situacionista, muito embora para ele estivessem disponíveis o aparato policial e o erário público. A oposição, também, se predominasse em algum reduto eleitoral, procuraria, por meio dos mesmos procedimentos levianos, influenciar a composição das mesas eleitorais e a apuração dos votos. Sobre esse caos político, adscreve Assis Brasil: "Ninguém tinha a certeza de se fazer qualificar, como a de votar ...Votando, ninguém tinha a certeza de que lhe fosse contado o voto ...Uma vez contado o voto, ninguém tinha a segurança de que seu eleito havia de ser reconhecido... ${ }^{6}$.

Por sua vez, os 'coronéis' exerciam a sua influência por intermédio do voto de cabresto, determinando aos eleitores do interior os candidatos em que deveriam votar. Para esse eleitorado, pobre e de poucas luzes, os votos valiam 'recompensas' do patrão, enquanto a desobediência poderia resultar em punições violentas. Não votando em quem o coronel mandasse, sujeitavase o 'eleitor' a perder seu emprego e a não obter outro na região ${ }^{7}$.

6 CUNHA, Jânio Pereira da; VALENTE NETO, José. O papel da justiça eleitoral na consolidação da democracia: eleições de 1994-96, Disponivel em $<$ http://72.14.209.104/search?q=cache:vtbhfHjAaXIJ:www.pgm.fortaleza.ce.gov.br/ revistaPGM/vol09/11PapelJusticaEleitoral.htm + justi $\% \mathrm{C} 3 \% \mathrm{~A} 7 \mathrm{a}+$ eleitoral $+32+$ degola\&hl=pt$\mathrm{BR} \& \mathrm{gl}=\mathrm{br} \& \mathrm{ct}=\mathrm{clnk} \& \mathrm{~cd}=24 \& \mathrm{lr}=$ lang $\mathrm{pt}>$. Acesso em 16.12.2007.

7 Até a Revolução de 30 , o eleitor recebia o envelope lacrado e com a cédula já previamente marcada. Só ele não sabia em quem havia "votado".

Revista Esmat, Palmas, Ano 3, n 3, pag. 177 a 206 - jan/dez 2011 
No meio deste processo, como uma das formas de garantir a liberdade do voto do eleitor, no ano de 1932 criou-se a Justiça Eleitoral editando-se o Código Eleitoral, ocorre que somente no ano de 1934 sua existência foi consolidada na Constituição Federal, período este de rompimento com os desmandos do coronelismo e da prática do voto de cabresto. ${ }^{8}$ Nesta época o País ganhou um poder independente cabendo a ele administrar toda a matéria inerente às eleições, desde o cadastramento dos eleitores da aferição dos candidatos até a apuração e divulgação dos resultados e a diplomação dos eleitos, antes ao encargo das mesas eleitorais.

Pela luta da democracia plena o Código Eleitoral (Decreto 21.076/32, de 24/02/1932) estabeleceu, como regra, a vedação da prisão do eleitor desde 5 (cinco) dias antes e até 24 (vinte e quatro) horas posteriores ao dia da eleição, salvo na hipótese de flagrante delito, nos seguintes termos:

Art. 98. Ficam assegurados aos eleitores os direitos e garantias ao exercício do voto, nos termos seguintes:

$\S 1^{\circ}$ Ninguém pode impedir ou embaraçar o exercício do sufrágio.

$\S 2^{\circ}$ Nenhuma autoridade pode, desde cinco dias antes e até 24 horas depois do encerramento da eleição, prender ou deter qualquer eleitor, salvo flagrante delito.

$\S 3^{\circ}$ Desde 24 horas antes até 24 horas depois da eleição, não se permitirão comícios, manifestações ou reuniões públicas, de caráter político.

$\S 4^{\circ}$ Nenhuma autoridade estranha à Mesa Receptora pode

8 Cláudio da Silva Leira, Disponivel em: <http://jus2.uol.com.br/doutrina/texto. asp?id=10498 $>$. Acesso em 16/12/2007. 
intervir, sob pretexto algum, em seu funcionamento.

$\S 5^{\circ}$ Os membros das Mesas Receptoras, os fiscais de candidatos e os delegados de partido são invioláveis durante o exercício de suas funções, não podendo ser presos, ou detidos, salvo flagrante delito em crime inafiançável.

$\S 6^{\circ}$ É proibida, durante o ato eleitoral, a presença de força pública dentro do edifício em que funcione a Mesa Receptora ou nas suas imediações.

$\S 7^{\circ}$ Será feriado nacional o dia da eleição.

$\S 8^{\circ} \mathrm{O}$ Tribunal, Superior e os Tribunais Regionais darão habeas-corpus para fazer cessar qualquer coação ou violência atual ou iminente.

$\S 9^{\circ}$ Nos casos urgentes, o habeas-corpus poderá ser requerido ao juiz eleitoral, que o decidirá sem demora, com recurso necessário para o Tribunal Regional.

Logo depois, no ano de 1935, entrou em vigor a Lei $\mathrm{n}^{\circ}$ 48, que modificou o Código Eleitoral. Acresceu nos direitos * e as garantias do eleitor ao exercício do voto a possibilidade de prisão do eleitor no período eleitoral em razão de sentença criminal condenatória por crimes inafiançáveis, dispondo em seu art. 165 o seguinte:

Art. 165. Serão assegurados aos eleitores os direitos e garantias ao exercicio do voto, nos termos seguintes:

1) ninguem poderá impedir ou embaraçar a exercicio do suffragio;

2) nenhuma autoridade poderá, desde cinco dias antes e até vinte e quatro horas depois do encerramento da eleição, prender ou deter qualquer eleitor, salvo em flagrante delicto ou em virtude de sentença criminal condenatória por crime inafiançável ;

3) desde quarenta e oito horas antes, até vinte e quatro horas depois da eleição, não se permittirá propaganda politica, 
mediante radio-diffusão, ou em comicios, ou reuniões publicas ;

4) nenhuma autoridade estranha á, mesa receptora poderá intervir, sob pretexto algum, em seu funccionamento;

5) os membros das mesas receptoras, os candidatos, os fiscaes de candidatos e os delegados de partidos serão inviolaveis durante o exercicio de suas funcções, não podendo ser presos, ou detidos, salvo em flagrante delicto; 6) é prohibida, durante o acto eleitoral, a presença de força publica no edificio em que funccionar a mesa receptora, ou nas suas immediações, observado o disposto no art. 128, $\S 50$;

7) será feriado nacionaI, estadual ou municipal o dia de eleição;

8) o Tribunal Superior e os tribunaes regionaes darão Habeas-corpus e mandado de segurança para fazer cessar qualquer coacção ou violencia, actual ou imminente, ao exercicio do direito de voto de propaganda politica;

9) em casos urgentes o habeas-corpus e o mandado de segurança poderão ser requeridos ao juiz eleitoral, que o decidirá sem demora, com recurso necessario para o Tribunal Regional;

10) é vedade, aos jornaes officiaes da União, Estados, Districto Federal, Territorio e Municipios, a propaganda politica em favor de candidato ou partido contra outros. (redação original)

No ano de 1937, foi outorgada nova Constituição pelo então Presidente Getúlio Vargas, que anunciou pela rádio a "nova ordem" do País, extinguiu a Justiça Eleitoral, aboliu os partidos políticos existentes, nomeou interventores para o Poder Executivo Estadual e Municipal, suspendeu as eleições livres e estabeleceu eleição indireta para Presidente da República com mandato de seis anos. 
Somente no ano de 1945 é que editaram o Decreto Lei ${ }^{\circ}$ 7.586 - a Lei Agamenom ${ }^{9}$ - que restabeleceu a Justiça Eleitoral, e dentro das garantias eleitorais aumentou o prazo de vedação de prisão do eleitor após o encerramento da eleição de 24 horas para 48 horas, onde se vê em seu artigo 108:

Art. 108. São assegurados aos eleitores os direitos e garantias ao exercício do voto, nos termos seguintes:

1) ninguém poderá impedir ou embaraçar o exercício do sufrágio;

2) nenhuma autoridade poderá, desde cinco dias antes e até quarenta e oito horas depois do encerramento da eleição, prender ou deter qualquer eleitor, salvo em flagrante delito ou em virtude de sentença criminal condenatória por crime inafiançável;

3) desde quarenta e oito horas antes, até vinte e quatro horas depois da eleição, não se permitirá propaganda política, mediante radiodifusão, em comícios, ou reuniões públicas; 4) nenhuma autoridade estranha à mesa receptora poderá intervir, sob pretexto algum, em seu funcionamento;

5) os membros das mesas receptoras, os fiscais de candidatos ou os delegados de partidos são invioláveis, durante o exercício de suas funções, não podendo ser presos, ou detidos, salvo em flagrante delito;

6) é proibida, durante o ato eleitoral, a presença de força pública no edifício em que funcionar a mesa receptora, ou nas suas imediações, observado o disposto no art. 76 , parágrafo único;

7) não se aplica a Lei Constitucional n. ${ }^{\circ} 2$, de 16 de maio de 1938, aos Juízes e funcionários a que incumbir o serviço eleitoral, em qualquer de suas modalidades.

9 Agamenom Magalhães erro o Ministro da Justiça, responsável pela elaboração do Decreto-Lei. 
As mudanças eram rápidas e no ano de 1950, sob todas as pressões políticas o legislador preocupado com as condições dos candidatos dentro dos 15 dias que antecedem as eleições, período decisivo para a vitória, garantiu a restrição de sua prisão por meio da Lei $\mathrm{n}^{\circ} 1.164$, que assim definiu:

Art. 129. São assegurados aos eleitores os direitos e garantias de exercício do voto, nos termos seguintes:

1) ninguém poderá impedir ou embaraçar o exercício de sufrágio;

2) nenhuma autoridade poderá, desde cinco dias antes e até quarenta e oito horas depois do encerramento da eleição, prender ou deter qualquer eleitor, salvo em flagrante delito ou em virtude de sentença criminal condenatória por crime inafiançável;

3) desde quarenta e oito horas antes, até vinte e quatro horas depois da eleição, não se permitirá propaganda política mediante radiodifusão, comícios ou reuniões públicas;

4) os membros das mesas receptoras e os fiscais de partido, durante o exercício das suas funções, não poderão ser detidos ou presos, salvo o caso de flagrante delito; da mesma garantia gozarão os candidatos desde quinze dias antes da eleição;

5) é proibida, durante o ato eleitoral, a presença de força pública, no edifício em que funcionar a mesa receptora, ou nas mediações, observado o disposto no art. 83, parágrafo único;

6) a realização de qualquer ato de propaganda partidária ou eleitoral, que deva ter lugar em recinto aberto, fica apenas subordinada a comunicação por ofício ou telegrama à autoridade competente, que somente poderá designar o local para a reunião, contanto que, assim procedendo, não a frustre ou impossibilite;

7) é vedado aos jornais oficiais, estações de rádio e tipografias de propriedade da União, dos Estados, Distrito 
e Territórios federais, municípios, autarquias e sociedades de economia mista, a propaganda política favorável ou contrária a qualquer cidadão ou partido;

8) as estações de rádio, mencionadas no inciso, precedente, nos quinze dias anteriores a uma eleição, proporcionarão meia hora diária de irradiação aos órgãos da Justiça Eleitoral, para a divulgação de esclarecimentos referentes ao processo eleitoral.

Art. 130. As estações de rádio, com exceção das referidas no artigo anterior e das de potência inferior a dez kilowatts, nos noventa dias anteriores às eleições gerais de todo o país ou de cada circunscrição eleitoral, reservarão diariamente duas horas à propaganda partidária, sendo uma delas pelo menos à noite, destinando-as, sob rigoroso critério de rotatividade, aos diferentes partidos, mediante tabela de preços iguais para todos.

Art. 131. A propaganda eleitoral, qualquer que seja a sua forma, só poderá ser feita em língua nacional.

$\S 1^{\circ}$ Os infratores deste artigo ficam sujeitos à pena de três a seis meses de prisão, além da apreensão e perda do material de propaganda, qualquer que seja o meio de divulgação.

$\S 2^{\circ} \mathrm{O}$ processo para apuração do fato a que se refere este artigo é o das contravenções penais.

$\S 3^{\circ}$ Sem prejuízo do processo e da pena constante deste artigo, o juiz eleitoral, o preparador e as autoridades policiais e municipais impossibilitarão imediatamente a propaganda.

Segundo afirma SADER ${ }^{10}$ a "ordem social" foi restabelecida em dois tempos: um primeiro ciclo repressivo se deu a partir de 1964, outro a partir de 1968. Sempre sob a vigência dos Atos Institucionais, o governo manteve o poder de cassação sobre um Congresso amedrontado e um Judiciário subserviente".

$10 \quad$ Op. cit. p. 22

Revista Esmat, Palmas, Ano 3, n 3, pag. 177 a 206 - jan/dez 2011 
Dentro deste espaço de tempo a Lei $\mathrm{n}^{\circ} 1.164 / 50$ foi substituída pela Lei $\mathrm{n}^{\circ}{ }^{4} 4.767 / 65$, que se encontra parcialmente em vigor até os presentes dias e mais conhecida como Código Eleitoral Brasileiro, que no tocante à possibilidade de prisão no período eleitoral acrescentou a hipótese do salvo-conduto:

Art. 236. Nenhuma autoridade poderá, desde 5 (cinco) dias antes e até 48 (quarenta e oito) horas depois do encerramento da eleição, prender ou deter qualquer eleitor, salvo em flagrante delito ou em virtude de sentença criminal condenatória por crime inafiançável, ou, ainda, por desrespeito a salvo-conduto.

$\S 1^{\circ}$. Os membros das Mesas Receptoras e os Fiscais de partido, durante o exercício de suas funções, não poderão ser detidos ou presos, salvo o caso de flagrante delito; da mesma garantia gozarão os candidatos desde 15 (quinze) dias antes da eleição.

$\S 2^{\circ}$. Ocorrendo qualquer prisão o preso será imediatamente conduzido à presença do Juiz competente que, se verificar a ilegalidade da detenção, a relaxará e promoverá a responsabilidade do coator.

Sem dúvida alguma, a meta objetivada pelo legislador, com a proibição da prisão, conforme o teor do artigo 236 do Código Eleitoral, é a de evitar pressões políticas, abusos e armações capazes de influenciar o eleitor ou colocar em dúvida o resultado da apuração.

Essa garantia fez parte de uma fase da nossa história, hoje o direito do indivíduo devidamente alistado como eleitor, ao voto livre de ameaças, mandados de prisões imotivadas ou arbitrárias, grupos partidários com ânimos acirrados já não 
fazem parte do cenário político deste País, ademais este Direito Político bem como outros foram transplantados para o Capítulo IV, do Título I - Dos Direitos e Garantias Fundamentais do elenco constitucional vigente, fortalecendo a estrutura da democracia e o respeito à cidadania.

\section{APLICAÇÃO DO ARTIGO 236 DO CÓDIGO ELEITORAL E A DEFESA DO DIREITO A ALIMENTOS E DA OBRIGAÇÃO ALIMENTAR}

Desde os primórdios o homem tem lutado incessantemente contra o arbítrio e os diversos tipos de violência física ou mental. A sociedade brasileira vive em um regime político democrático representativo e participativo no qual busca alcançar os valores da maioria, da igualdade e da liberdade.

Para a defesa de uma democracia participativa o que importa é a convivência harmônica entre o homem do povo e as autoridades policial ou pública em geral e garantir qualquer espécie de coação ou constrangimento ilegal do qual o "sufrágio ou o voto são instrumentos formais pelos quais os cidadãos exercem o poder de escolha." "11

Para os juízes eleitorais o dia da eleição, que é o dia da realização desta "democracia", ainda é um momento de preocupação face ao dever de assegurar ao eleitor, o direito ao exercício do voto livre e consciente, proibindo-se a prática de

11 VIEIRA, Oscar Vilhena. Direitos Fundamentais: uma leitura da jurisprudência do STF. São Paulo: FGV, Malheiros, 2006, p. 625. 
atos que o tolhem no livre exercício do sagrado direito do voto e constrangedor no sentido de não poder fazer valer suas decisões de entrega do bem jurídico conflitado.

Em conseqüência do que foi exposto, estão vedadas, na interpretação 'tradicional' do artigo 236 do Código Eleitoral, as prisões temporárias; prisões preventivas; as decorrentes de sentença de pronúncia e de sentenças condenatórias por crimes afiançáveis; a prisão do depositário infiel, bem como a prisão do eleitor devedor de alimentos por não estar albergada pelas exceções do citado dispositivo legal, conforme ensinam PEDRO ROBERTO DECOMAIN e PÉRICLES PRADE (2004, p. 300). ${ }^{12}$

No universo das situações que o eleitor se encontrar 5 (cinco) dias antes das eleições e 48 (quarenta e oito) hora após o término da votação, as quais foram previstas pelo legislador no ano de 1965 é assegurado à todo cidadão eleitor o direito de se socorrer do salvo-conduto, previsto no artigo 235 do Código Eleitoral.

A essência desta garantia, por muito tempo era aceitável como medida preventiva para os abusos, armações capazes de influenciar o eleitor nas vésperas das eleições e forma de evitar acirramento de ânimos. Em visão mais esclarecida do dispositivo cotejado, aduz com inteira propriedade RIBEIRO que,

não apenas contra autoridade policial ou autoridade pública em geral, dispondo de maior elastério, recaindo contra qualquer pessoa que esteja a ocasionar gravame, físico

12 Cláudio da Silva Leiria, pág. 13, extraído do <http://jus2.uol.com.br/doutrina/texto. asp?id=10498>. Acesso em 16/12/2007. 
ou moral, à liberdade de voto. Nessas condições, o salvoconduto poderá ser emitido em favor do eleitor em virtude de coação emanada de patrão contra o seu empregado, do proprietário contra os seus colonos ou rendeiros, do dirigente sindical contra associados, do diretor de estabelecimento de ensino contra os seus discípulos, do chefe de família contra o outro cônjuge, seus filhos e dependentes, enfim, genericamente, contra quem quer que esteja a cometer violência moral ou física sobre o desempenho do eleitor no ato de votação ${ }^{13}$

Ante essas circunstâncias legítimas, constata-se um desconforto dos juristas em geral com a rigidez do texto legal e arcaico, para os tempos atuais, inadequado para fazer frente às inúmeras hipóteses que o jurisdicionado pode necessitar de tutelas de urgência e extrema durante o período eleitoral como nos casos de decretarem-se prisões civis por dívidas de alimentos, com efeito os operadores do Direito são obrigados a fazer novas interpretações sobre o artigo 236 do Código Eleitoral, flexibilizando-o em atendimento ao direito constitucional à vida do ser humano em situação de risco visível e premente diante do comportamento negligente do alimentante e ao princípio da efetividade do processo na tutela de vários direitos que reclamam brevidade, sob pena de perecimento. 


\subsection{Revogação e Inconstitucionalidade do art. 236 do Código Eleitoral}

Cresce no meio jurídico um número considerável de defensores para afirmar a revogação e a inconstitucionalidade do artigo 236 do Código Eleitoral. Que na visão dos críticos este artigo poderia estar criando um supercidadão, que no período especificado não poderia ser preso.

O especialista em Direito Eleitoral, professor. $\mathrm{CÂNDIDO}^{14}$, no plano doutrinário é um dos precursores que afirma a revogação do artigo 236 do Código Eleitoral. E o faz nos seguintes termos:

Hoje, com a vigência do art. $5^{\circ}$, LXI, da Constituição Federal, o art. 236 e $\S 1^{\circ}$, do Código Eleitoral, está revogado. Mesmo fora daqueles períodos, ninguém pode ser preso, a não ser nas exceções mencionadas na lei. E pelas exceções constitucionais a prisão será legal, podendo ser efetuada mesmo dentro dos períodos aludidos no Código Eleitoral. Em resumo: se a prisão não for nos moldes da Constituição Federal, nunca poderá ser efetuada; dentro dos limites da Constituição Federal pode sempre ser executada, mesmo em época de eleição.

Na visão de RAMAYANA o artigo 236 da Lei n ${ }^{\circ} 4.737 / 65$ é simplesmente desnecessário, vez que

consagra o artigo legal evidente exagero, que não mais merece permanecer na ordem jurídica, pois os motivos 
que embasaram o legislador para a adoção da regra não prevalecem nos tempos atuais ${ }^{15}$.

Importante referir que no Congresso Nacional tramita o Projeto de Lei $n .^{0} 7.573 / 2006^{16}$, de autoria do Deputado Fernando de Fabinho (PFL-BA), que propõe a revogação pura e simples do artigo 236 do Código Eleitoral. A redação do projeto é a seguinte:

"PROJETO DE LEI N. ${ }^{\circ} 7.573 / 2006$

Revoga o art. 236 do Código Eleitoral. O Congresso Nacional decreta:

Art. $1^{\circ}$. Esta lei revoga o art. 236 da Lei n. ${ }^{\circ} 4.737$, de 15 de julho de 1965, que institui o Código Eleitoral, de maneira a relativizar o princípio do direito de voto diante do princípio da segurança da sociedade, permitindo em todo o território nacional a prisão dos cidadãos, mesmo no período compreendido entre os cinco dias que antecedem e as quarenta e oito horas que se sucedem à eleição.

Art. $2^{\circ}$. Revogue-se o art. 236 da Lei n. ${ }^{\circ} 4.737$, de 15 de julho de 1965.

Art. $3^{\circ}$. Esta lei entra em vigor na data de sua publicação."

$\mathrm{Na}$ justificativa do projeto de lei, Sua Excelência faz as seguintes e judiciosas considerações, que certamente externam

15 RAMAYANA, Marcos. (2004, p. 353)

16 Projeto de lei apensado ao projeto de lei $3.735 / 200$, de autoria do Deputado Dr. Hélio (PDT-SP), que visa acrescer, às ressalvas contra a prisão ou detenção de qualquer eleitor, no período compreendido entre os cinco dias anteriores e as quarenta e oito horas após o encerramento do pleito eleitoral, a hipótese de cumprimento de mandado de prisão expedido por autoridade judiciária competente, nos casos tipificados como crimes hediondos, assim definidos pela Lei n. ${ }^{\circ} 8.072$, de 25 de julho de 1990.

Revista Esmat, Palmas, Ano 3, n 3, pag. 177 a 206 - jan/dez 2011 
o pensamento de respeitável parcela da comunidade jurídica e do povo em geral:

...sopesando o direito de voto e o direito de segurança da sociedade contra os individuos que atentam contra os valores que lhe são caros, o legislador preferiu o primeiro, estabelecendo algumas exceções. No entanto, passadas mais de quatro décadas da entrada em vigor da norma e vivendo nós hoje em um mundo muito mais violento, penso que não mais se justifica tal garantia eleitoral. O livre exercício do sufrágio há de ser garantido de outra forma, mas não mais dando um salvo-conduto de uma semana a inúmeros criminosos, para que circulem tranqüilamente no período das eleições ${ }^{17}$.

Nesse sentido, oportunas são as lições de GERALDO FRANCISCO PINHEIRO FRANCO, que sustenta em seu artigo “A prisão de eleitores nas vésperas da eleição" que o preceito do artigo 236 da Lei n. ${ }^{\circ}$ 4.737/65 visa, em razão da importância de um pleito eleitoral para a Nação, evitar embaraços ilícitos ao exercício de voto. No entanto, fundado o impedimento em ordem judicial ou inquérito policial, em sede de segregação cautelar, não há como considerar tal circunstância um óbice ilícito ao exercício do sufrágio."

Essa linha de idéias desafia novamente a aplicação da técnica de interpretação conforme a Constituição. O enfoque dado pelo autor sugere que a vedação à prisão nos prazos do art. 236 do CE diz respeito, tão-somente, aos embaraços ilícitos para o exercício do sufrágio, e não à normal atividade jurisdicional

17 Texto extraido do Artigo do Cláudio da Silva Leiria. 
de decretação de prisões, sejam elas cautelares ou definitivas. ${ }^{18}$

\section{JUDICIÁRIO E GARANTIAS DOS DIREITOS FUNDAMENTAIS}

Partimos do pressuposto de que o direito fundamental seja ele a liberdade de voto do eleitor ou o direito aos alimentos são, primariamente, direitos cujos titulares são pessoas, individualmente consideradas, ou grupos sociais e ao Judiciário cabe à sua imediata aplicação.

Seguindo o caminho dos estudos de $\mathrm{ROCHA}^{19}$, de que ao Judiciário caiba, apenas, "aplicar" os direitos fundamentais, a verdade é que aplicação nunca é uma operação "mecânica”, como insinua a doutrina circulante, já que pressupõe a "interprestação", o que complica a questão em estudo, como veremos adiante. De modo que o Judiciário viola também os direitos fundamentais, quando de sua interpretação, seja limitando-lhes o conteúdo normativo essencial, seja negando-lhes aplicação.

Indiscutivelmente o Estado vem sofrendo mudanças em seu papel, que passa de garantidor da ordem social no dia das Eleições para promotor de mudanças sociais. Neste contexto, a função do Judiciário que de aplicador de normas cogentes tendentes a reprimir as condutas violadoras de regras de manutenção da paz social, converte-se em partícipe do

18 Apud texto de Cláudio da Silva Leiria, p. 19

19 ROCHA, José de Albuquerque. Estudos sobre o Poder Judiciário. São Paulo: Malheiros, 1995 , p. 67 
processo de criação do direito e aplicador dessas mesmas regras observando sempre os critérios de conveniência e oportunidade destinadas a estimular com o fim de transformar as realidades concretas.

Nessa linha de raciocínio continua o doutrinador ROCHA $^{20}$ :

as garantias constitucionais dos direitos em geral e dos direitos fundamentais em particular só adquirem sentido quando se dispõe de um aparelho judiciário apto a transforma-las em realidades concretas. Fora disso, não passam de declarações de intenções.

O processualista moderno está comprometido com resultados e o magistrado com a capacidade de resolver conflitos, ser eficiente na prestação da tutela jurisdicional e produzir estes resultados respeitando todos os princípios fundamentais constitucionais para segurança jurídica, melhoria e progresso na aplicação do Direito.

A sociedade atual espera da justiça efetividade em seus julgados e o Estado surgiu para garantir e proteger, igualmente, a cada cidadão na sua individualidade sem sacrificar a garantia da orem pública.

$\mathrm{O}$ apego do magistrado às formalidades legais, sem responsabilidade com a Justiça, é uma conseqüência do positivismo jurídico do século passado, fundamentado em hipóteses enunciadas por Platão e Aristóteles, segundo as 
quais "um governo de lei é melhor do que um governo de homens", Hoje, não tem lugar a essa assertiva, mas pode-se dizer o contrário: 'Um governo de homens é melhor do que um governo de lei' ${ }^{21}$.

Nas condições históricas em que vivemos, a garantia do direito ao voto deve ser relativizada em prol do bem mais precioso que o homem possui que é o

direito à vida como prioridade absoluta e determina a efetivação de políticas públicas que permitam o nascimento e o desenvolvimento sadio e harmonioso.Em condições dignas de existência ${ }^{22}$.

O direito ao voto pode ser compatibilizado com a pertinência da prisão civil por dívidas de alimentos, bastando ' que o Estado crie meios para que o alimentante preso possa ser conduzido a local de votação no dia do pleito eleitoral.

Neste contexto evidencia a importância dos alimentos, execução e prisão civil como medida de coação pessoal e mecanismo de garantia para efetividade da justiça e que se necessário for a privação de liberdade do impontual de suas obrigações alimentícias deve ser cumprida com maior rigor em nome da garantia dos direitos e interesses individuais, difusos e coletivos, representando uma evolução do processo civilizatório estando ele sobreposto ao direito do voto.

21 BEZERRA, Joseane de Jesus Corrêa, Monografias, ESMAM, São Luiz-MA, p. 623. 22 PEREIRA, Tânia da Silva, Direito da Criança e do Adolescente, Renovar, 1996, p. 127. 


\section{CONCLUSÃO}

A problemática vivida na véspera das Eleições na atuação repressiva das autoridades judiciárias para o cumprimento dos mandados de prisão civil por dívidas alimentícias durante os períodos previstos do artigo 236 da Lei 4.767/65 - Código Eleitoral Brasileiro, que tem refletido no Poder Judiciário, está intimamente relacionado com a estrutura do legalismo arcaico e resquício das garantias eleitorais justificadas no ano de 1932, período repressor e ditatorial.

A meta objetivada com a vedação da prisão era a de evitar abusos, prisões imotivadas ou arbitrárias, "processos forjados", denúncias "pré-fabricadas", e ainda armações políticas dos "coronéis" e "ditadores", capazes de influenciar o eleitor ou colocar em dúvida o resultado da apuração.

São relevantes os fundamentos utilizados pelo Deputado Fernando de Fabinho (PFL-BA) no Projeto de Lei n ${ }^{\circ} 7573 / 2006$, que defende $\mathrm{a}$ inconstitucionalidade da vedação à prisão do eleitor em nome da segurança jurídica da sociedade.

$\mathrm{O}$ aparato judiciário da prisão Civil por dívida alimentar justifica-se em caráter excepcional e como instrumento de persuasão do alimentante, por ter sido insuficiente os meios de coerção patrimonial e, que a determinação da segregação objetiva preservar precipuamente o direito a garantia e preservação do direito à vida do alimentado de maneira eficaz.

Se determinado momento tem-se conflito de direitos fundamentais, protegidos constitucionalmente o direito à vida 
e à sobrevivência está sobreposto ao direito do eleitor de votar, cabendo ao Estado proporcionar meios e condição favorável ao preso provisório possa exercer seu direito de voto como ato máximo da cidadania.

\section{REFERÊNCIAS BIBLIOGRÁFICAS}

APOSTOLOVA, Bistra Stefanova. Poder Judiciário: Do moderno ao Contemporâneo. Porto Alegre: Sérgio Antonio Fabris Editor, 1998.

BASTOS, Celso Ribeiro. Curso de Teoria do Estado e Ciência Política. 6 ed. São Paulo: Celso Basto Editor, 2004.

, BOBBIO, Norberto. A era dos direitos. $12^{\mathrm{a}}$ Tiragem. Rio de Janeiro: Campus, 1992.

CÂNDIDO, Joel João. Direito Eleitoral Brasileiro. $11^{\mathrm{a}}$ ed. rev. atual. Bauru-SP: Edipro, 2005.

CARVAlHO, José Murilo de. Cidadania no Brasil. Rio de Janeiro: Civilização Brasileira, 2001.

CUNHA, Jânio Pereira da; VALENTE NETO, José. O papel da Justiça Eleitoral na "consolidação da democracia: Eleições de 1994-96 Disponível em <http://72.14.209.104/ search? q=cache:vtbhfHjAaXIJ:www.pgm.fortaleza. 
ce.gov.br/revistaPGM/vol09/11 PapelJusticaEleitoral. $\mathrm{htm}+\mathrm{justi} \% \mathrm{C} 3 \% \mathrm{~A} 7 \mathrm{a}+$ eleitoral $+32+\mathrm{degola} \& \mathrm{hl}=\mathrm{pt}-$ $\mathrm{BR} \& \mathrm{gl}=\mathrm{br} \& \mathrm{ct}=\mathrm{clnk} \& \mathrm{~cd}=24 \& \operatorname{lr}=\operatorname{lang} \mathrm{pt}>, \quad$ acesso $\quad$ em 16.12.2007.

DECOMAIN, Pedro Roberto, e PRADE, Péricles, Comentários ao Código Eleitoral. São Paulo: Editora Dialética, 2004.

DINIZ, Maria Helena. Curso de Direito Civil Brasileiro. 18 ed. Saraiva: São Paulo, 2002. 5.v

DÓRIA, A. Sampaio. Direito Constitucional. $5^{\mathrm{a}}$ edição, vol. I, Tomo I, São Paulo: Max Limonad, 1962.

FARIAS, Edilsom Pereira. Colisão de Direitos: a honra, a intimidade, a vida privada e a imagem versus a liberdade de expressão e informação. Porto Alegre, Sérgio Antonio Fabris Editor, 1996.

FERREIRA, Manoel Rodrigues. A Evolução do Sistema Brasileiro Eleitoral Brasileiro. Brasília: Conselho Editorial do Senado Federal, 2001.

LAGES, José Brígido da Silva. et. al. Monografias. São Luís: Edições ESMAM, 2007.

LEIRA, Cláudio da Silva. Considerações sobre o artigo 236 
do Código Eleitoral. Disponível em: $<$ http://jus2.uol.com.br/ doutrina/texto.asp?id=10498 $>$ acesso em 16/12/2007.

MORAES, Alexandre de. Direito Constitucional. 20 ed. Atual. São Paulo: Atlas, 2006.

MÜLLER, Friedrich. Quem é o Povo? A questão fundamental da democracia. $3^{\text {a }}$ edição Revista e Atualizada, Max Limonad:

PEREIRA, Tânia da Silva. Direito da Criança e do Adolescente. Rio de Janeiro: Renovar, 1996.

NICOLAU, Jairo. História do voto no Brasil. 2 ed. Rio de Janeiro: Jorge Zahar, 2004.

RAMAYANA, Marcos. Código Eleitoral Comentado. Rio de Janeiro: Roma Victor Editora, 2004.

RIBEIRO, Fávila. Direito Eleitoral. $5^{\mathrm{a}}$ edição, $3^{\mathrm{a}}$ tiragem. Rio de Janeiro: Editora Forense, 2000.

ROCHA, José de Albuquerque. Estudos sobre o Poder Judiciário. São Paulo: Malheiros, 1995.

SADER, Emir. A Transição no Brasil - Da Ditadura à Democracia? São Paulo: Atual, 1990. 
SILVA, José Afonso da. Curso de Direito Constitucional Positivo. 26 ed, ver. e atual. São Paulo: Malheiros, 2006.

STOCCO, Rui, e STOCCO, Leandro de Oliveira. Legislação Eleitoral Interpretada - Doutrina e Jurisprudência. São Paulo: Editora Revista dos Tribunais, 2004.

TAVARES, André Ramos. Curso de Direito constitucional. São Paulo: Saraiva, 2006.

VERONESE, Josiane Rose Petry. Interesses Difusos e Direitos da Criança e do Adolescente. Belo Horizonte: Del Rey, 1996.

VERONESE, Josiane Rose Petry. Temas de Direito da Criança e do Adolescente. São Paulo: LTr, 1997.

VIEIRA, Oscar Vilhena. Direitos Fundamentais: uma leitura da jurisprudência do STF. São Paulo: FGV, Malheiros, 2006. 